\title{
Conservation status of Taxus floridana, a critically endangered evergreen coniferous plant
}

\author{
Ejaz Ahmed*, Yamin Bibi, Muhammad Arshad and Kaleem Ullah \\ Department of Botany, PMAS-Arid Agriculture University Rawalpindi, Pakistan \\ Corresponding Author: ejazabbasi2001@yahoo.com \\ Citation \\ Ejaz Ahmed, Yamin Bibi, Muhammad Arshad and Kaleem Ullah. Conservation status of Taxus floridana, \\ acritically endangered evergreen coniferous Plant. Pure and Applied Biology. Vol. 3, Issue 4, 2014, pp 188-191
}

\begin{abstract}
Taxus floridana Nutt. ex Chapm. is a slow growing, evergreen, coniferous plant restricted along the Apalachicola river in north-western Florida. Owing to its confinement to a small area and its declining population the specie is regarded as critically endangered plant according to IUCN. Besides its slow growth, many factors led to severe decline in the population of this species in past few decades. Ripened cones of T. Floridana are an important source of food for many bird species, beavers chew off the tops of young stems and white tailed-deer also rubs on these trees. Florida yew is also highly sensitive to fire. T. floridana also contains an important anticancer drug "Paclitaxel" which is also found in Taxus brevifolia and T. Canadensis. Paclitaxel is used in the treatment of various forms of cancer. These entire factors led to serious decline in the population of this species in past few decades. Florida yew is ideal to be used as hedge or in foundation planting but it seldom appears in nurseries. T. Floridana should be used in home landscapes in order to avoid its extinction. T. floridana can also be propagated through stem cuttings. It has been observed that mature wood cuttings taken in winter root well under mist. Several conservation studies and efforts were made to conserve it like other species of the same genus, but a more comprehensive and multipleapproach conservation strategy is required to ensure its conservation. Long term monitoring programs and propagation studies may prove fruitful in conserving such critically endangered species.
\end{abstract}

Key Words: Critically endangered plant, Taxus floridana

\section{Introduction}

\section{Distribution of Taxus floridana}

Taxus floridana Nutt.exChapm. is the scientific name of Florida Yew [1]. Taxus floridana (Fig. 1) is endemic species of Florida. This plant is restricted to a small area of bluffs and ravines along the Apalachicola River in north-western Florida (Fig.2). These habitats typically lie at an altitude of $15-30 \mathrm{~m}$, where it occurs with an even rarer endemic conifer species Torreya taxifolia [2, 3]. Several populations of Florida yew were also reported along a $24 \mathrm{Km}$ stretch of the river in Gadsden and Liberty counties $[4,5]$. A single population was also reported in an Atlantic White-Cedar Swamp about $13 \mathrm{Km}$ southeast of Bristol, Florida [6]. The Nature Conservancy have reported that Atlantic White-Cedar swamp population do not exist in present times [4]. Many of the plants are also growing in privately owned land areas.

Habitat and Community Structure

Taxus floridana is usually present in moist, shady ravines in hardwood forests, where soils are mostly acidic to neutral sandy loams [4]. The species usually occurs in small clonal strands and individual stems appear at very rare. T. floridana in its endemic habitat is dominated by Ilex glabra, Magnolia grandiflora, Quercus laurifolia, Torreya taxifolia and Fagus grandifolia [7]. 


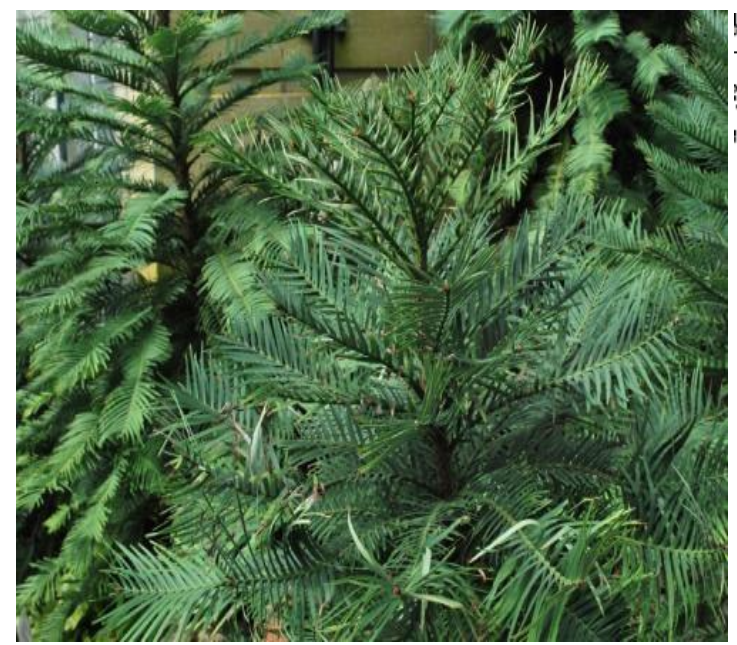

Fig. 1: Taxus floridana

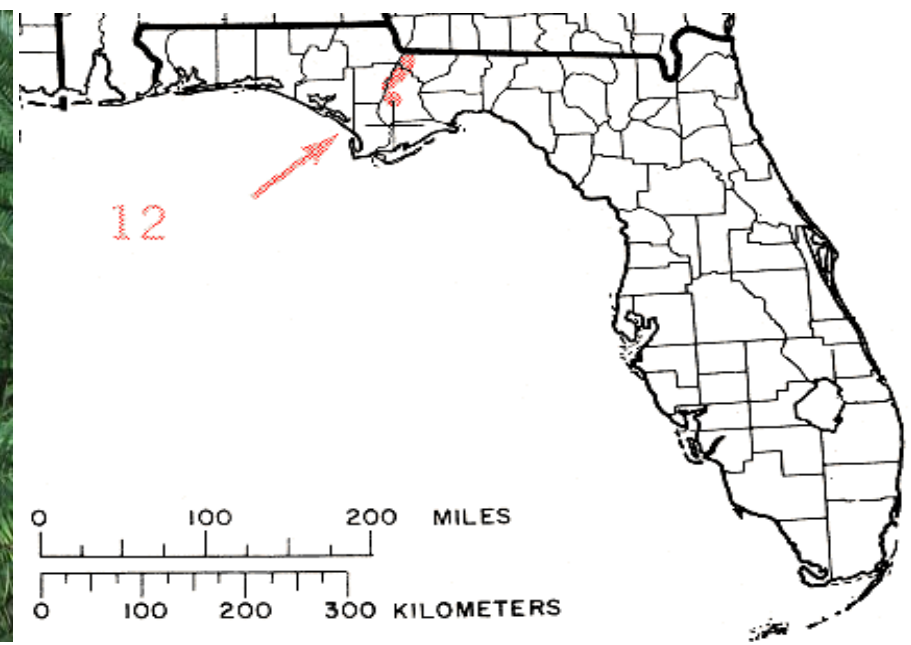

Fig. 2: Distribution of Taxus floridana

\section{Morphological Description}

T. floridana is a dioecious evergreen shrub or small tree about $10 \mathrm{~m}$ tall and $38 \mathrm{~cm}$ dbh. T. Floridana belongs to Phanerophytes of Raunkiar life forms [8, 9]. It develops irregular crown with spreading numerous branching. Its bark is purple-brown and smooth initially but with advancing age, it develops irregular scales. Its leaves are needle like, pliable, dark green, slightly falcate on the upper side while light green with two stomatal bands on the underside. Even though the wood is hard when it is dried but when alive it is flexible. Male cones formed along the shoots are yellow, solitary with $2-3 \mathrm{~mm}$ of diameter. Female cones are formed on underside of shoots are initially fleshy green wile on maturity become orange to red. Each female cone possesses a single seed measuring 5-6mm long and ellipsoidal in shape [2].

\section{Conservation status}

Taxus floridana Nutt.ex Chapm. is a critically endangered plant and its IUCN category and criteria is "Critically Endangered B1ab(iii,v) ver3.1"[10]. This category includes those plants which have very limited population or occurrence and are going to become extinct in wild in near future.The major reason behind its placement in the above category is that its extent of occurrence (EOO) is less than $100 \mathrm{Km}^{2}$, which is only $24 \mathrm{Km}^{2}$. Other factors include lack of regeneration and the impact of increasing deer population. Moreover the adult mortality rate is more than the recruitment leading to an overall decline in the population; therefore it is listed as critically endangered plant in IUCN red list of species [11].

\section{Phytochemical characteristics}

T. floridana contains the same important anticancer drug "Paclitaxel" found in Taxus brevifolia and $T$.
Canadensis [12]. Paclitaxel is found in the bark and needles of this plant. Paclitaxel is the generic name of drug "Taxol" used in the treatment of lung cancer, ovarian cancer, breast, head and neck cancer [13].

\section{Importance of Taxus floridana}

Despite the presence of Paclitaxel, Ripened Florida yew cones are an important source of many bird species which consume them completely. Beavers also chew off the tops of young stems and white tailed-deer also rubs on these trees. Mature trees of Florida yew are also excavated by Yellow-bellied sapsuckers, making holes for inhabitation of many insects [7].

Studies on conservation of $\boldsymbol{T}$. floridana

Owing to the slow growth of Florida yew and endemic to a very small area of hardwood ravine forests of Apalachicola River Bluffs region of northern Florida[14-18], the species is considered globally rare $[19,20]$ and endangered in the state of Florida [21, 22]. Kwit et al. [19] performed a conservational effort by investigating the demography of $T$. floridana as a rare understory conifer in three populations in different ravine forests studying its entire geographic range alongside the Apalachicola River Bluffs in northern Florida. Spatial and temporal patterns were examined in demographic parameters and using four years of data population growth rates were assessed. The recruitment and survival of seedlings and established stems were also examined. It was found that about ten-fold increase was noted in all population's seedling recruitment in first year compared with other years. Stochastic matrix models projected declines in all population's growth rates. They concluded that conservation efforts directed at long-lived, slow growing rare 
plants like Taxus floridana should protect established reproductive individuals and further enhance survival of individuals in other life history stages such as juveniles that often do not directly contribute to population growth [19].

\section{Threats towards its extinction and controls}

Florida yew is present in forests which may be subjected to logging and private development [23]. Presence of Taxol in similar quantities and its exploitation like those of T. brevifolia, T. Canadensis and $T$. baccata, may pose a danger to its population. In-vitro production of taxol may mimic the population decline of yew species.

Florida yew also occurs in some areas which have been protected like The Nature Conservancy's "Apalachicola Bluffs and Ravines Preserve" and "Torreya State Park" but many populations are still without any specific protection [24-26]. Some populations of Florida yew are also present in privately owned land and are not under protection. The major reason for this fact is that no such laws are effective across the world for protection of plant species in privately owned land. Formulation of such laws would be a milestone in the preservation of many such endangered species across the world.

Florida yew is a shade loving plant and is highly sensitive to fire so fire effects are highly detrimental to its population [27]. Due to the presence of these plants in humid forests however fires do not usually affect these plants and damaged plants may show sprouting but are of low vigour and usually do not survive [14]. Increase in global temperature and climate change may decrease their propagation and population density.

Study of all subpopulations showed that $T$. floridana is mainly present in the form of multi-stemmed individuals where stem densities range from several hundred to several thousand per hectare. Individual stem are relatively short lived and Small sized stems are especially more vulnerable to browsing and rubbing by deer. Though the plants produce seeds, but propagation through seedlings is very slow and varies among sites. The majority of seedlings occur under female trees and seedling growth is negatively affected by the density and presence of canopy. In a case study by Redmond, 1984one hundred seedlings were tagged in each of the two sites, twenty one and thirty nine percent seedlings survived to ten months respectively in both cases. Seedlings are moderately shade tolerant and a very low level of seedling recruitment was observed at sites having a closed canopy. Seedling establishment and survival is also observed to be very low in deep shades. A study of four subpopulations over last 27 years showed that adult mortality rate is more than recruitment. For
Taxus spp. the only successful methods of propagation are layering and sprouting [18, 28].

During $19^{\text {th }}$ century felling of Pinus palustris forests with selective logging of the slope forests have resulted in range reduction and habitat fragmentation during the nineteenth and twentieth centuries. Another important threat faced by Florida yew is the lack of its regeneration, the causal agent for that has not been established so far [29].

Florida yew grows in the form of dense clonal strands, which make it ideal to be used as hedge plant or in foundation planting but it seldom appears in nurseries. It should be used in home landscapes in order to avoid its extinction. Like other species of Taxus, T. floridana can also be propagated through stem cuttings $[30,31]$. It has been observed that mature wood cuttings taken in winter root well under mist.

\section{Conclusions}

Taxus floridana is a slow growing, evergreen, coniferous plant, restricted to a small region in northern Florida. Due to slow growth and declining population it is listed as critically endangered plant in IUCN red list of species. There are a number of potential factors responsible for declining its population to an alarming level. Several conservation studies and efforts were made to conserve it, but a more comprehensive and multiple-approach conservation strategy is required to ensure its conservation. Long term monitoring programs and propagation studies may prove fruitful in conserving such critically endangered species.

\section{References}

1. Little EL (1979). Checklist of United States trees (native and naturalized). Agric. Handb. 541. Washington, DC: U.S. Department of Agriculture, Forest Service. 375 p.

2. Hils MH (1993). Taxaceae. Flora of North America Editorial Committee (eds.): Flora of North America, Vol. 2. Oxford University Press, New York.

3. Southeastern Wildlife Services, Inc. (1982). A distribution survey of thepopulations of Taxus floridana and Torreya taxifolia in Florida.Contract No.: 14-16-0004-81-069. Atlanta, GA: U.S. Department of the Interior, Fish and Wildlife Service. 11 p. On file with: U.S. Department of Agriculture, Forest Service, Intermountain Research Station, Fire Sciences Lab, Missoula, MT.

4. Guala S (1993). Element stewardship abstract for Taxus floridana, Florida yew. Arlington, Virginia: The Nature Conservancy. 8 p. On file at: U.S. Department of Agriculture, Forest Service, Intermountain Research Station, Fire Sciences.

5. Godfrey RK (1988). Trees, shrubs, and woody vines of northern Florida and adjacent Georgia and 
Alabama. Athens, GA: The University of Georgia Press. 734 p.

6. Kurz H (1927). A new and remarkable habitat for the endemic Florida yew. Torreya. 27: 90-92.

7. Sullivan J (1993). Taxus floridana. In: Fire Effects Information System, USDA Forest Service, Rocky Mountain Research Station, Fire Sciences Laboratory.

8. Raunkiaer C (1905). Typesbiologiques pour la géographiebotanique. Oversigt over DetKongeligeDanskeVidenskabernesSelskabsForhan dlinger, pp 347-438.

9. Raunkiaer C (1934). The Life Forms of Plants and Statistical Plant Geography, being the collected papers of C. Raunkiaer. Oxford University Press, Oxford. Reprinted 1978 (ed. by Frank N. Egerton), Ayer Co Pub., in the "History of Ecology Series". ISBN 0-405-10418-9.

10. http://www.iucnredlist.org/details/30965/0

11. Spector T, Thomas P \& Determann R (2011). Taxus floridana. In: IUCN 2012. IUCN Red List of Threatened Species.Ver. 2012.2.

12. Koppaka V, Rajendra R, Bhakuni S, Juchum J \& Davies RM, (1996). A large scale process for Paclitaxel and other Taxanes from the needles of Taxus x Media Hicksii and Taxus floridana using reverse phase column chromatography. J. liquid Chromatography and related technologies. 19(3): 427-447.

13. Zhong JJ (2002). Plant cell culture for production of paclitaxel and other taxanes.-J. Biosci. Bioeng. 94: 591-599.

14. Bolsinger CL, Jaramillo \& Annabelle E (1990). Taxus brevifolia Nutt. Pacific yew. In: Burns, Russell M.; Honkala, Barbara H., technical coordinators. Silvics of North America. Volume 1. Conifers. Agric. Handb. 654. Washington, DC: U.S. Department of Agriculture, Forest Service: pp573579.

15. Schwartz MW (1994). Natural distribution and abundance of forest species and communities in northern Florida. Ecology 75:687-705.

16. Kwit C, Schwartz MW, Platt WJ, \& Geaghan JP (1998). The distribution of tree species in steepheads of the Apalachicola River Bluffs, Florida. Journal of the Torrey Botanical Society 125:309-318.

17. Škrlep K, Bergant M, De Winter GM, Bohanec B, Žel J, Verpoorte R, Van IF \& Camloh M (2008). Cryopreservation of cell suspension cultures of Taxus $\times$ media and Taxus floridana. Biologia Plantarum. 52 (2):329-333.

18. Redmond AM (1984). Population ecology of Taxus floridana, a passively cloning dioecious tree. M.S. thesis. Florida State University, Tallahassee.
19. Kwit C, Horvitz CC, \& Platt WJ (2004). Conserving Slow-Growing, Long-Lived Tree Species: Input from the Demography of a Rare Understory Conifer, Taxus floridana. Conservation Biology, 18: 432-443.

20. Silvertown J, Franco M, Pisanty I, \& Mendoza A (1993). Comparative plant demography: relative importance of life-cycle componentsto the finite rate of increase in woody and herbaceous perennials. Journal of Ecology 81: 465-476.

21. U.S. Fish and Wildlife Service (USFWS). (1981). A distribution survey of the populations of Taxus floridana and Torreya taxifolia in Florida. Unpublished report. Contract 13-16-0003-81069.USFWS, Atlanta, Georgia.

22. Wood D \& Compiler A (1994). Official lists of endangered \& potentially endangered fauna and flora in Florida. Tallahassee, FL: Florida Game and Fresh Water Fish Commission. pp 21- 22.

23. Delcourt HR, \& Delcourt PA (1977) Presettlement magnolia-beech climax of the Gulf coastal plain: quantitative evidence from the Apalachicola River bluffs, north-central Florida. Ecology 58:1085- 1093.

24. Enright NJ, \& Watson AD (1991). A matrix population model analysis for the tropical tree, Araucaria cunninghamii. Australian Journal of Ecology.16:507-520.

25. Marks PL \& Harcombe PA (1981). Forest vegetation of the Big Thicket, southeast Texas. Ecological Monographs. 51:287-305.

26. Roovers LM, \& Rebertus A.J (1993). Stand dynamics and conservation of an old-growth Engelmann spruce-subalpine fir forest inColorado. Natural Areas Journal 13:256-267.

27. David S, Kelly \& Eugene M (1988). Rare plant monitoring and prescribed burning initiated at the Apalachicola Bluffs and Ravines Preserve (Florida). Restoration \& Management Notes. 6(2): 91.

28. Cardel Y, Rico-Gray V, Garcia-Franco JG, \& Thien LB (1997). Ecological status of Beaucarnea gracilis, an endemic species of the semiarid Tehuacan Valley, Mexico. Conservation Biology 11:367-374.

29. Minore D, Weatherly HG \& Cartmill M. (1996). Seeds, seedlings, and growth of the Pacific yew (Taxus brevifolia). Northwest Science. 70:223-229.

30. Pilger RKF (1903). Taxaceae. V. 18[IV, 5] p. 1-124 in H.G.A. Engler, ed., 1900 - 1953. Berlin: Das Pflanzenreich.

31. Zuidema PA \& Boot RGA (2002). Demography of the Brazil nuttree (Bertholletia excelsa) in the Bolivian Amazon: impact of seedextraction on recruitment and population dynamics. Journal of Tropical Ecology.18:1-31. 